\title{
Comparison of stainless and mild steel welding fumes in generation of reactive oxygen species
}

\author{
Stephen S Leonard*, Bean T Chen, Samuel G Stone, Diane Schwegler-Berry, Allison J Kenyon, David Frazer,
} James M Antonini

\begin{abstract}
Background: Welding fumes consist of a wide range of complex metal oxide particles which can be deposited in all regions of the respiratory tract. The welding aerosol is not homogeneous and is generated mostly from the electrode/wire. Over 390,000 welders were reported in the U.S. in 2008 while over 1 million full-time welders were working worldwide. Many health effects are presently under investigation from exposure to welding fumes. Welding fume pulmonary effects have been associated with bronchitis, metal fume fever, cancer and functional changes in the lung. Our investigation focused on the generation of free radicals and reactive oxygen species from stainless and mild steel welding fumes generated by a gas metal arc robotic welder. An inhalation exposure chamber located at NIOSH was used to collect the welding fume particles.

Results: Our results show that hydroxyl radicals $(\mathrm{OH})$ were generated from reactions with $\mathrm{H}_{2} \mathrm{O}_{2}$ and after exposure to cells. Catalase reduced the generation of $\cdot \mathrm{OH}$ from exposed cells indicating the involvement of $\mathrm{H}_{2} \mathrm{O}_{2}$. The welding fume suspension also showed the ability to cause lipid peroxidation, effect $\mathrm{O}_{2}$ consumption, induce $\mathrm{H}_{2} \mathrm{O}_{2}$ generation in cells, and cause DNA damage.

Conclusion: Increase in oxidative damage observed in the cellular exposures correlated well with ${ }^{\circ} \mathrm{OH}$ generation in size and type of welding fumes, indicating the influence of metal type and transition state on radical production as well as associated damage. Our results demonstrate that both types of welding fumes are able to generate ROS and ROS-related damage over a range of particle sizes; however, the stainless steel fumes consistently showed a significantly higher reactivity and radical generation capacity. The chemical composition of the steel had a significant impact on the ROS generation capacity with the stainless steel containing $\mathrm{Cr}$ and $\mathrm{Ni}$ causing more damage than the mild steel. Our results suggest that welding fumes may cause acute lung injury. Since type of fume generated, particle size, and elapsed time after generation of the welding exposure are significant factors in radical generation and particle deposition these factors should be considered when developing protective strategies.
\end{abstract}

\section{Background}

There are approximately 390,000 full-time welders in the United States [1] and an estimated 5 million persons occupationally exposed to welding fumes worldwide. The welding process which joins materials by causing coalescence using a filler material, usually wire, to form a molten pool which then cools bonding the surfaces together. During this process an occupational exposure can occur through inhalation of the fume and particles.

\footnotetext{
* Correspondence: SEL5@CDC.GOV

Pathology and Physiology Research Branch, Health Effects Laboratory Division, National Institute for Occupational Safety and Health, Morgantown, WV, USA
}

(c) 2010 Leonard et al; licensee BioMed Central Ltd. This is an Open Access article distributed under the terms of the Creative Commons Attribution License (http://creativecommons.org/licenses/by/2.0), which permits unrestricted use, distribution, and reproduction in any medium, provided the original work is properly cited. Although full-time welders may be easier to track, the welders who may also be exposed as well as others working in the vicinity of the welding activities. These part-time and cross workplace exposures make the effects difficult to monitor. Welding is frequently carried out in areas with poor ventilation such as ship hulls, metal tanks, or pipe and crawl spaces leading to a greater potential for exposure. Welding fumes have been demonstrated to cause toxicity among exposed workers $[2,3]$ Welding fumes consist of a wide range of metal oxide particles, including iron, manganese, chromium, and nickel, which are generated mostly from the 
electrode/wire feed [4]. Two of the major feed wire types which are used in the welding process are mild steel (MS) and stainless steel (SS).

Inhalation of the fume has been related to bronchitis [5], metal fume fever, occupational asthma [6] cancer and possible increases in lung tumorigenicity $[7,8]$, suppression of lung defenses [9,10], and functional changes in the lung [11-14]. Investigations have also shown an increase in ROS production after welding fume generation [15-17] and initiation of downstream mediators, such as HO-1, VEGF, and MAP kinases [18-20]. The generated fume ranges in size and can be deposited throughout the respiratory tract [4,21-23]. Previous studies have demonstrated the impact of particle size and surface area on pulmonary effects of inhaled toxicants [24].

The effects seen from exposure to welding fume are under investigation but not well understood nor are the mechanisms behind potential toxicity from fume exposure. However, the act of welding causes the generation of unstable metal oxides due to the energy at the point of the weld leading to an uncommon form of first exposure to newly formed unstable and potentially more reactive particles, similar to that seen in sandblasting [16,25-27]. Biological effects of welding fume exposure have been investigated employing cellular [28,29] and animal models [30] using a welding exposure system located at NIOSH Health Effects Laboratory Division. This system can simulate real workplace exposures and allows the collection of fresh welding fume from a continuous weld (figure 1). We used this automated system to collect welding fume from both SS wire and MS wire while using an arc welding process similar to that reported previously [22]. Differences in toxicity between mild steel and stainless steel fume have been previously observed [31,32]. Although, the reasons for these differences are not fully understood, some studies have indicated metal content in the weld wire as being the cause [33-35].

The goal of our study was to access differences in reactive oxygen species (ROS) generation during the welding process. This study will investigate the effects of weld wire type, particle size, surface area and time after generation of fume on the potential generation of ROS and its downstream effects. The observations reported here hope to elucidate the mechanism behind some of the biological effects observed in occupational exposures to welding fume.

\section{Results}

\section{Particle morphology and characteristics}

Electron micrographs of welding fume sample collected on MOUDI filters (Figure 2) showed large agglomerated chains of particles linked together which not only formed larger aggregate particles but greatly increased surface area. Particle sizes are not related to one single large particle but many smaller spherical particles linked as a chain which by its form creates a much greater surface area than would ordinarily be associated with a single spherical particle of this size. This greater surface

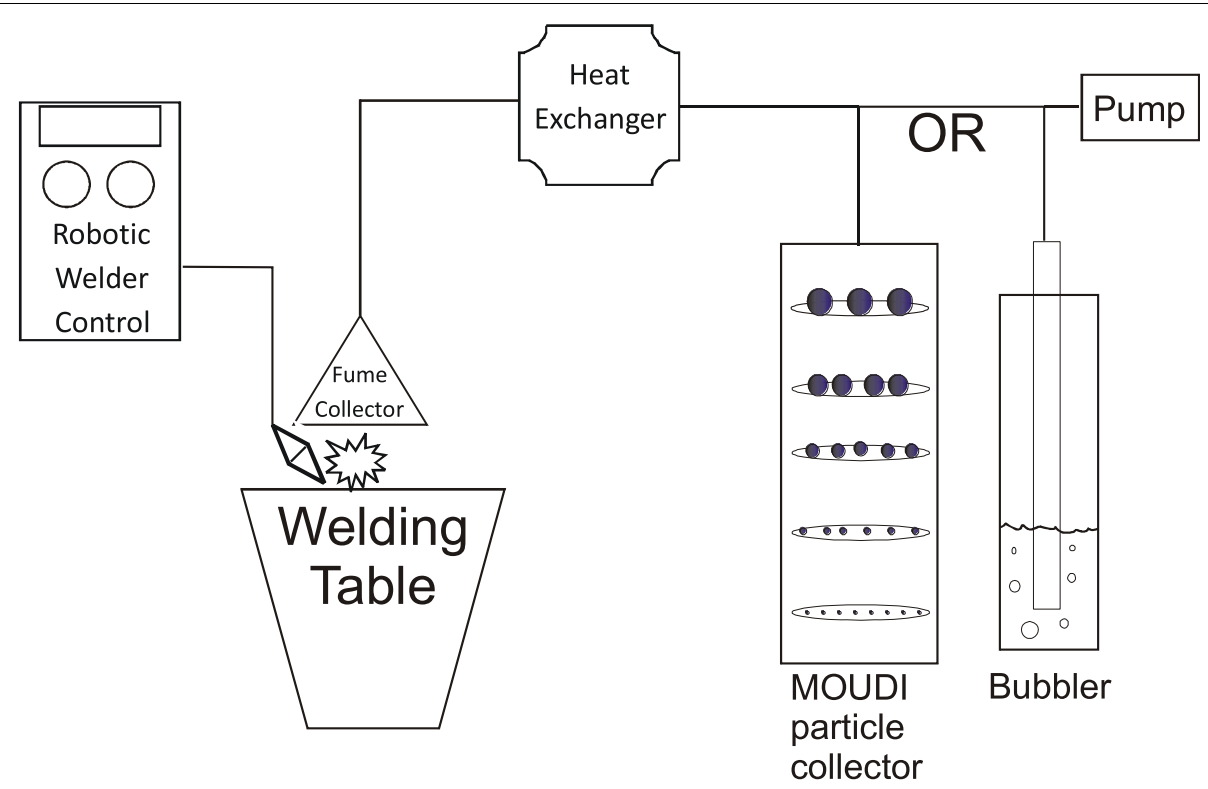

Figure 1 Schematic of the welding fume generation system. Welder operated from screened computer control room as welding occurs on a table. Generated fume collected immediately off the surface and passed through a heat exchanger then collected in the MOUDI particle collector or midget impinger. 

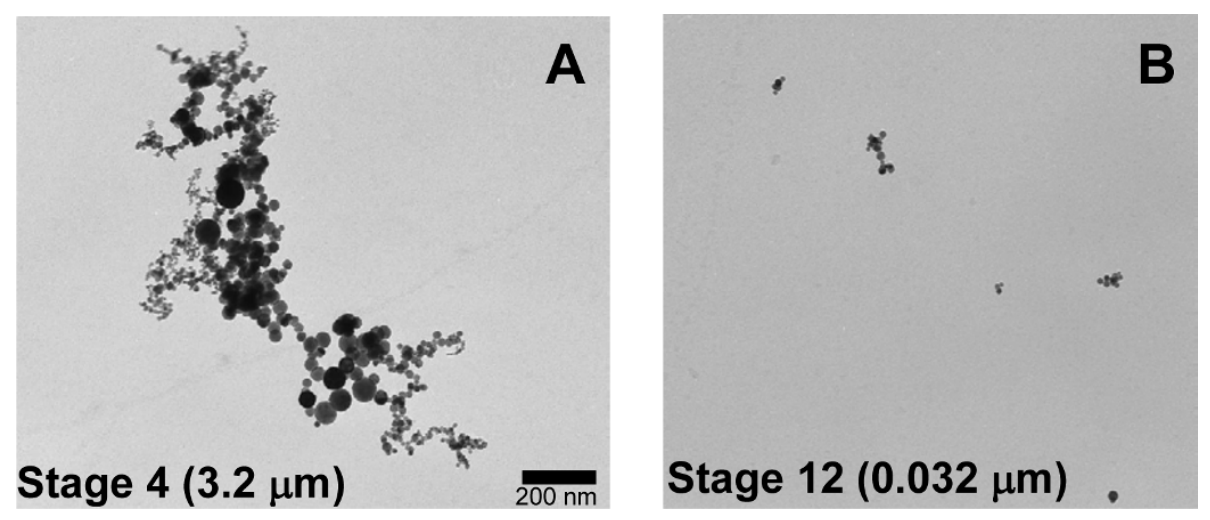

Figure 2 Electron micrographs of two of the 15 filters used in the MOUDI and nano-MOUDI. A) shows stage 4 (3.2 $\mu \mathrm{m}$ cut-off) larger particles and the formation of agglomerated chains of particles. B) shows stage 12 (0.032 $\mu \mathrm{m}$ cut-off) smaller individual particles and less chain formation.

area allows much more reaction surface with the generated fumes.

Most particles, calculated by mass, generated in our welding fume system were between 0.56 and $0.1 \mu \mathrm{m}$ in mean diameter as demonstrated in figure 3. This size range deposits mostly in the alveolar and bronchiolar regions in the lung; however, particles were found at all size ranges measured using the MOUDI. Note that even though grease was not used on the MOUDI stages in this study, the profile of the mass collected on the stages was similar to that obtained when the grease was used [22], demonstrating that the phenomenon of potential particle bounce, if any, was minimal.

Table 1 shows the elemental analysis of both stainless and mild steel wire which indicated that each wire contained $\mathrm{Fe}, \mathrm{Mn}$ and $\mathrm{Cu}$. However, stainless steel also contained the transition metals $\mathrm{Cr}(20.2 \pm 1.52 \% \mathrm{bw})$ and $\mathrm{Ni}(8.76 \pm 0.18 \% \mathrm{bw})$ while mild steel showed a small amount of $\mathrm{Si}(2.75 \pm 0.28 \% \mathrm{bw})$

\section{Free radical generation and ROS}

Free racial generation was examined using three separate systems; sized fume reaction with hydroxyl radical precursor $\mathrm{H}_{2} \mathrm{O}_{2}$, direct bubbling of whole fume through solution containing $\mathrm{H}_{2} \mathrm{O}_{2}$ and the spin trap DMPO, and sized fume effects on exposed cells.

Figure 4 shows individual filter sized welding fume reacting with hydrogen peroxide to measure generation of hydroxyl radical $(\cdot \mathrm{OH})$. Strong radical generation is observed at the 1 hour post collection time in both the

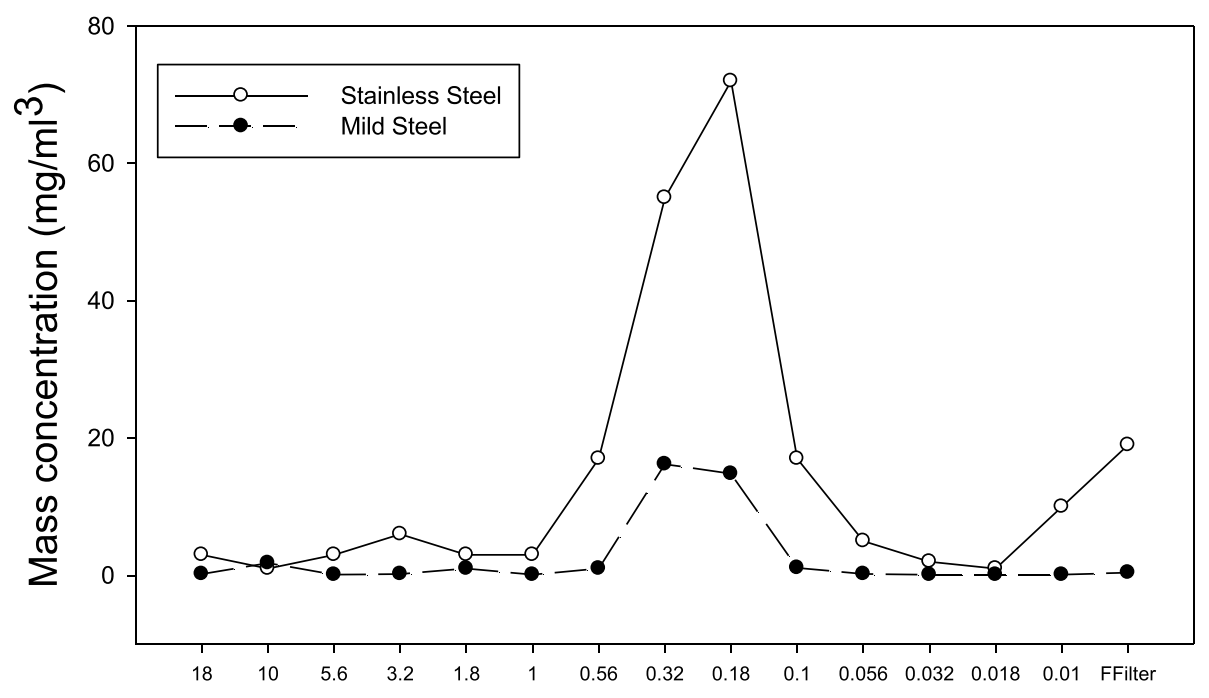

Filter mean aerodynamic dia $(\mu \mathrm{m})$

Figure 3 Mass concentration trapped on each filter of the MOUDI. 
Table 1 Stainless steel versus mild steel elemental analysis

\begin{tabular}{ccc}
\hline \multicolumn{3}{c}{ Stainless Steel } \\
\hline Metal & $\boldsymbol{\mu g} /$ sample & Weight $\%$ of metal \\
\hline $\mathrm{Fe}$ & $1207 \pm 161$ & $57 \pm 1.28$ \\
\hline $\mathrm{Cr}$ & $427.5 \pm 69.1$ & $20.2 \pm 1.52$ \\
\hline $\mathrm{Mn}$ & $295.0 \pm 48.4$ & $13.8 \pm 0.45$ \\
\hline $\mathrm{Ni}$ & $185 \pm 24.0$ & $8.76 \pm 0.18$ \\
\hline $\mathrm{Cu}$ & $3.30 \pm 0.492$ & $0.155 \pm 0.004$ \\
\hline \multicolumn{3}{c}{ Mild Steel } \\
\hline $\mathrm{Mn}$ & $776 \pm 9.8$ & $80.6 \pm 0.17$ \\
\hline $\mathrm{Si}$ & $142 \pm 2.0$ & $14.7 \pm 0.11$ \\
\hline $\mathrm{Cu}$ & $26.6 \pm 2.9$ & $2.75 \pm 0.28$ \\
\hline & $17.2 \pm 0.20$ & $1.79 \pm 0.02$
\end{tabular}

stainless steel and mild steel samples. The number of radicals generated is reduced over time as shown at the 24 hour and 1 week post generation. Using the $0.32 \mu \mathrm{m}$ mean aerodynamic diameter as a reference; stainless steel showed a $68 \%$ reduction in $\mathrm{OH}$ radical signal between 1 hour to 24 hours post generation which became a $77 \%$ reduction at the 1 week time point. Mild steel showed similar reduction over time with a $64 \%$ drop in $\mathrm{OH}$ signal from 1 hour to 24 hours and a $67 \%$ drop at the 1 week time point. The strongest ${ }^{\circ} \mathrm{OH}$ radical signals were measured at the $0.32 \mu \mathrm{m}$ to $0.056 \mu \mathrm{m}$ size ranges; however, it should be noted this closely corresponds to the observed higher mass collected at those sizes. When the $\mathrm{OH}$ radical signal was adjusted for particle weight/filter, mass normalized radical activity, it was observed that the smaller particles had increased radical generation potential per unit weight, figure 5 . Stainless steel showed higher generation of ${ }^{\circ} \mathrm{OH}$ radicals at every time point (except $5.6 \mu \mathrm{m}$ ) with significantly higher generation; $41 \%, 57 \%$ and $59 \%$ at sizes $0.1 \mu \mathrm{m}$, $0.056 \mu \mathrm{m}$, and $0.032 \mu \mathrm{m}$ respectively. Addition of deferoxamine, a metal chelator showed a decrease in radical signal strength in a concentration dependent manner with a complete abolishment of the $\mathrm{DMPO} / \mathrm{OH}$ signal at $2 \mathrm{mM}$ deferoxamine. Additon of catalase, an $\mathrm{H}_{2} \mathrm{O}_{2}$ catalyst, to the cellular reactions decreased the radical signal as well (data not shown).

Figure 6 shows the results of total fumes drawn directly from the welding surface and bubbled through PBS in the presence of $\mathrm{H}_{2} \mathrm{O}_{2}$ and DMPO, to act as a spin trap. Results demonstrate the total sample potential to generate $\mathrm{OH}$ radicals when reacted with $\mathrm{H}_{2} \mathrm{O}_{2}$. Stainless steel fumes showed a significantly higher generation of $\mathrm{OH}$ radicals than was an equal mass of fume generated by mild steel.

The results of RAW 264.7 cellular exposure to welding fume by size group and type of fume are shown in figure 7. Stainless steel fumes incubated with cells showed a significant increase at all three size groups when compared to mild steel fumes. There was also an increase in radical production within each steel type as particle size decreased. It should also be noted that the $\mathrm{Cr}(\mathrm{V})$ electron spin resonance signal (figure 7 inset)

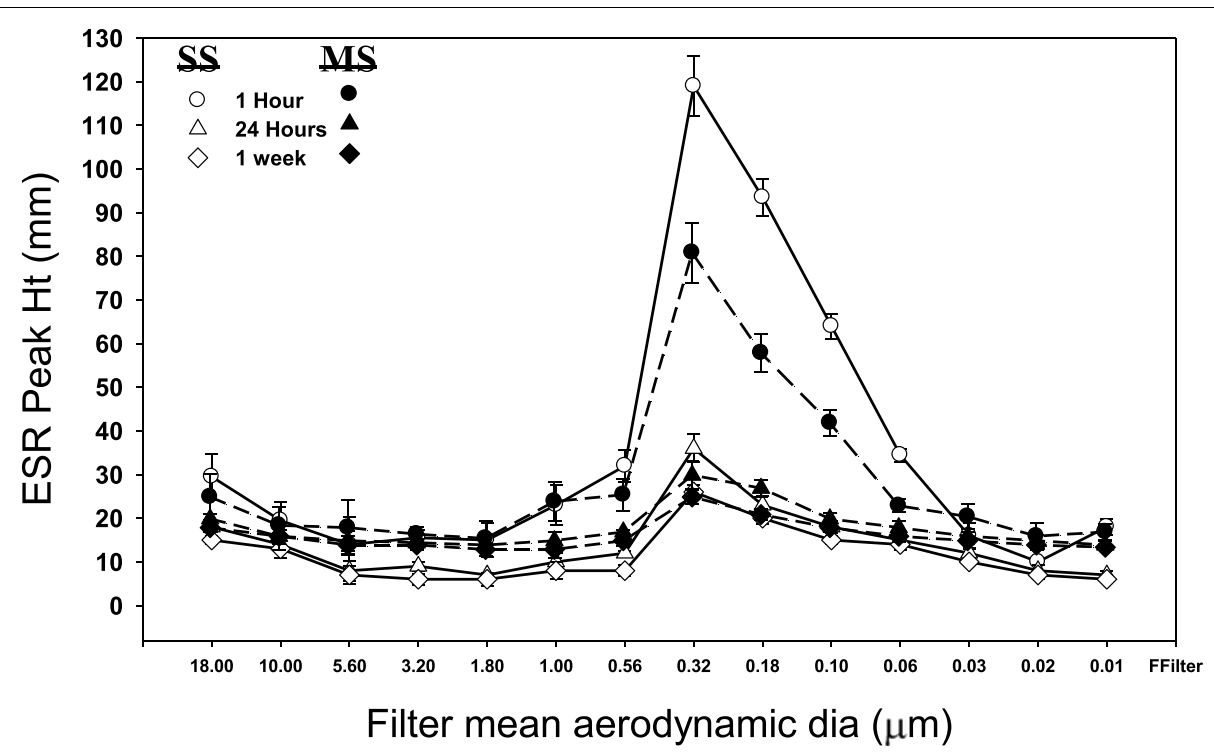

Figure 4 The generation of short-lived $\mathrm{OH}$ radicals upon reaction of $\mathrm{H}_{2} \mathrm{O}_{2}$ with individual filter sizes using different wire type and time periods after generation of fume. Open symbols represent stainless steel while filled symbols are mild steel wire. ESR spectrum recorded 3 min after reaction was initiated in PBS (pH 7.4), 1 mM H $\mathrm{O}_{2}$ and $100 \mathrm{mM}$ DMPO. ESR settings were; center field, 3385 G; scan width, $100 \mathrm{G}$; time constant, 40 msec; scans, 5; modulation amplitude, $1 \mathrm{G}$; receiver gain, $2.5 \times 10^{4}$; frequency, $9.793 \mathrm{GHz}$; and power, $63 \mathrm{~mW}$. 


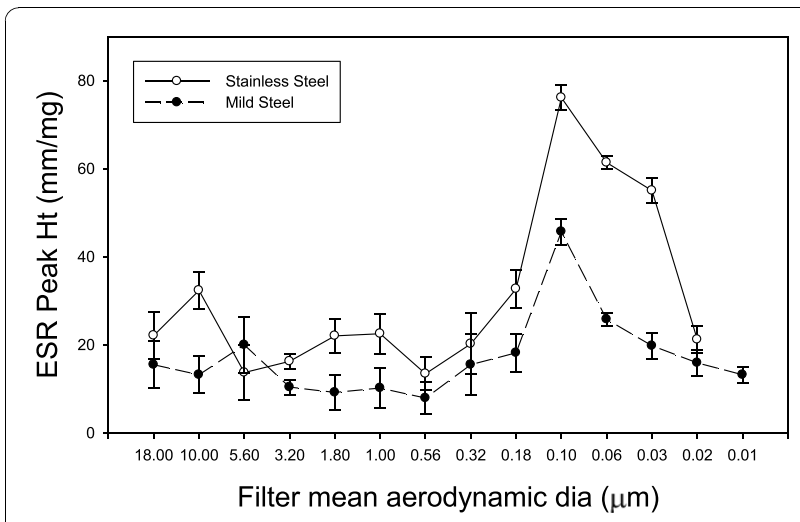

Figure 5 Mass normalized radical activity, $\mathrm{OH}$ radical peak heights of individual filters sizes adjusted for radicals $/ \mathrm{mg}$ on 1 hour post generation samples. ESR settings were; center field, 3385 G; scan width, $100 \mathrm{G}$; time constant, 40 msec; scans, 5; modulation amplitude, $1 \mathrm{G}$; receiver gain, $2.5 \times 10^{4}$; frequency, 9.793 $\mathrm{GHz}$; and power, $63 \mathrm{~mW}$. Asterisks indicate a significant increase in stainless steel fume compared to mild steel fume $(P<0.05)$.

was observed only in spectra from stainless steel fume exposure to cells.

\section{Lipid peroxidation}

Stainless steel fumes showed a significant increase in lipid peroxidation in exposed RAW 264.7 cells compared to control at all three sizes groups at equal mass as seen in figure 8 . Mild steel fumes caused a significant increase at the ultrafine particle size group. Stainless steel also showed a significant increase over mild steel when comparing fine and ultrafine size groups.

\section{$\mathrm{H}_{2} \mathrm{O}_{2}$ production}

Figure 9 shows the effects of welding fume on $\mathrm{H}_{2} \mathrm{O}_{2}$ generation after RAW 264.7 cells were exposure to welding fume. All welding fume sizes and steel types at equal mass showed a significant rise in $\mathrm{H}_{2} \mathrm{O}_{2}$ production in exposed RAW 264.7 cells when compared to control. A significant difference was also observed between stainless steel and mild steel fumes in the fine and ultrafine size groups. A size dependent increase in $\mathrm{H}_{2} \mathrm{O}_{2}$ production was also observed in both types of metals.

\section{$\mathrm{O}_{2}$ consumption}

A significant rise in oxygen consumption was observed in RAW 264.7 cells in all stainless steel size exposures and in the mild steel ultrafine size as shown in figure 10. A significant difference was observed between stainless steel fumes and mild steel fumes at equal mass in the ultrafine size group. A size dependent increase was also observed within steel types.

\section{DNA damage}

Comet assay results for DNA damage are shown in figure 11. The data demonstrates total grouped size filters for both stainless and mild steel at equal mass showed a significant increase in DNA damage in exposed RAW 264.7 cells. Furthermore, the stainless steel fumes caused

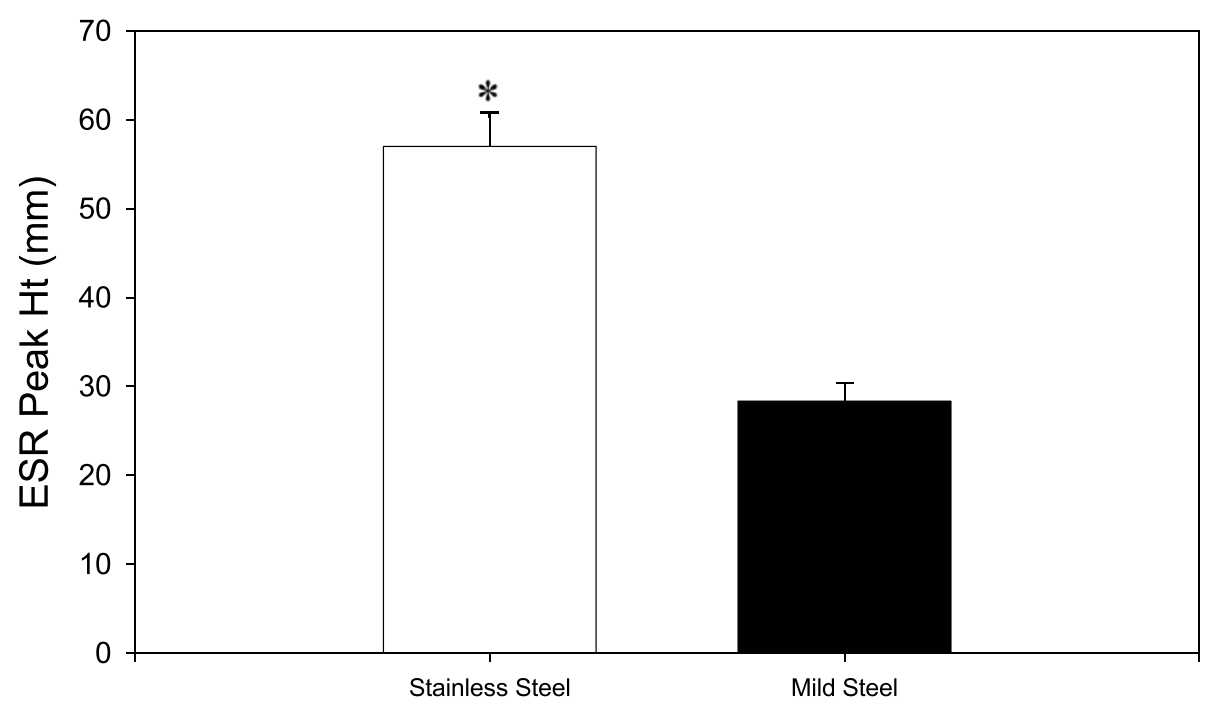

Figure $6 \mathbf{O H}$ radical peak heights of midget impinger bubbled samples. Flow rate $3.80 \mathrm{~L} / \mathrm{min}, 20 \mathrm{~min}$ collection time. Welding fume was bubbled directly through PBS (pH 7.4), 1 mM H $\mathrm{O}_{2}$ and $100 \mathrm{mM} \mathrm{DMPO.} \mathrm{ESR} \mathrm{settings} \mathrm{were;} \mathrm{center} \mathrm{field,} 3385$ G; scan width, 100 G; time constant, 40 msec; scans, 1; modulation amplitude, $1 \mathrm{G}$; receiver gain, $2.5 \times 10^{4}$; frequency, $9.793 \mathrm{GHz}$; and power, 63 mW. Asterisks indicate a significant increase in stainless steel fume compared to mild steel fume $(P<0.05)$. 


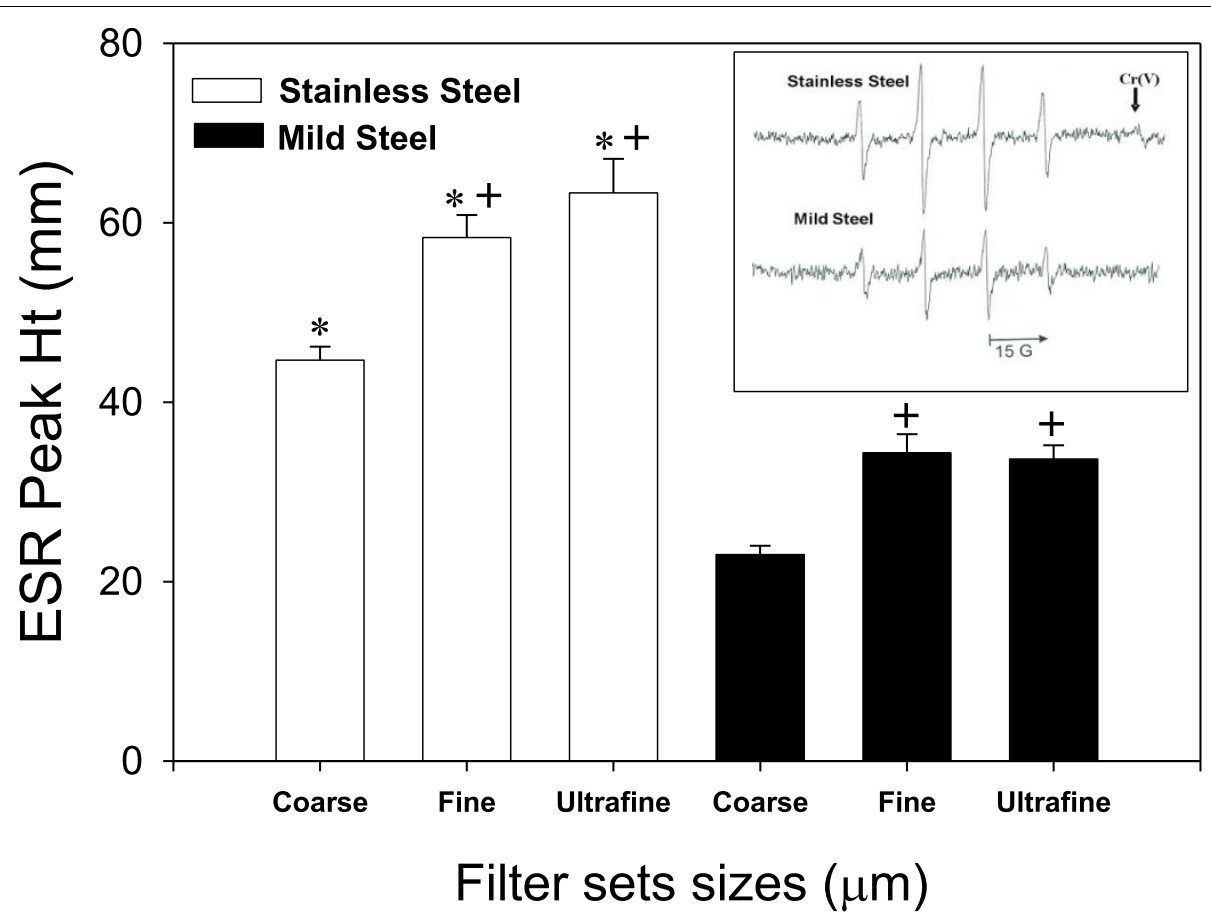

Figure 7 Radicals generated from RAW 264.7 cells $\left(1 \times 10^{6} / \mathrm{ml}\right)$ exposed to grouped filter sample welding fume $(250 \mu \mathrm{g} / \mathrm{ml})$ for 10 min at $37^{\circ} \mathrm{C}$ in a shaking water bath. ESR settings were; center field, $3385 \mathrm{G}$; scan width, $100 \mathrm{G}$; time constant, 40 msec; scans, 5; modulation amplitude, $1 \mathrm{G}$; receiver gain, $2.5 \times 10^{4}$; frequency, $9.793 \mathrm{GHz}$; and power, $63 \mathrm{~mW}$. Asterisks indicate a significant increase in radicals compared between steel types; $(+)$ indicate significant difference between fume sizes.

significantly more DNA damage when compared to mild steel fumes.

\section{Discussion}

The present study was undertaken to investigate possible radical generation of fume generated from two of the most common types of welding processes to access

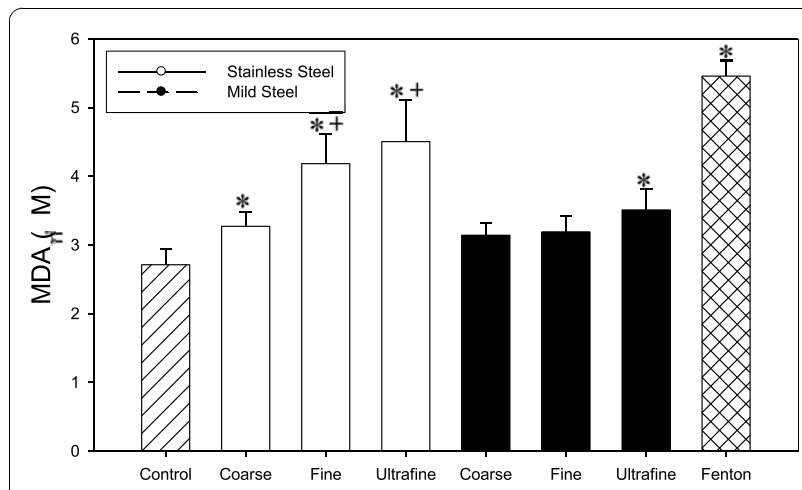

Figure 8 Welding fume induced lipid peroxidation in incubation mixture containing $250 \mu \mathrm{g} / \mathrm{ml}$ welding fume sample and $5 \times 10^{7}$ RAW 264.7 cells. Data presented are means of \pm S.D. for 4 sets of experiments. $\left(^{*}\right)$ indicate a significant increase in lipid peroxidation compared to control. (+) indicate significant difference between metal types at the same sizes. $(P<0.05)$ potential cellular damage from ROS generation and to determine if the biological effects were size, time and surface area dependent. Our results determined that both stainless steel and mild steel welding fumes are able to generate $\mathrm{OH}$ radicals in a Fenton-like system. These $\mathrm{OH}$ radials are precursors and initiators of many forms of ROS that can produce damage to cellular membranes, proteins and DNA as well as initiate further downstream damage and signaling associated with respiratory burst and inflammation. Our results also determined that freshly generated fume samples, 1 hour post, were significantly more reactive in generating $\mathrm{OH}$ radials than samples aged for 24 hours and 1 week. This reactivity is attributed to the change in transition states of the freshly generated metals that are produced during the welding process due to the high energy involved. Transition metals have the ability to accept and donate single electrons. Metals used in welding may temporarily attain a different and possibly more reactive, transition or valence state and in this changed transition state they are able to overcome the spin restriction on direct reaction of $\mathrm{O}_{2}$ with non-radicals. These reactions can lead to the generation of ROS and further damage to biological systems. Addition of metal clelators and catalase confirmed the involvement of metals and $\mathrm{H}_{2} \mathrm{O}_{2}$ in the radical generation observed. A consistent result 


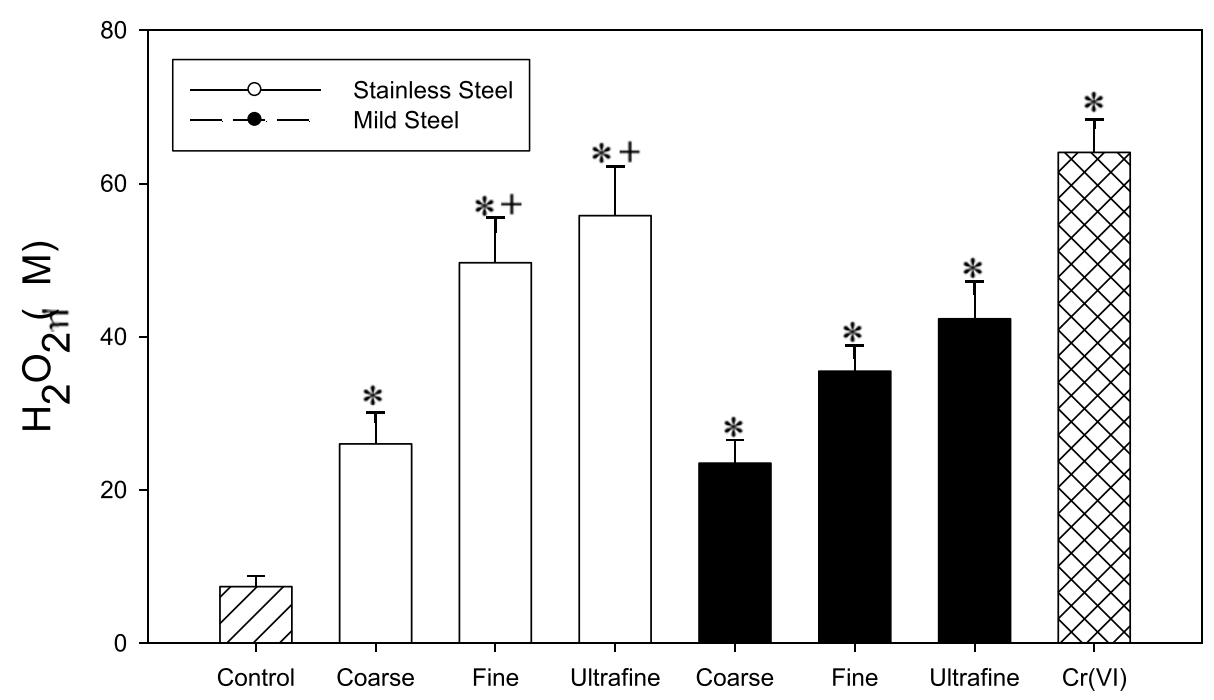

Figure $9 \mathrm{H}_{2} \mathrm{O}_{2}$ production in incubation mixtures containing $250 \mu \mathrm{g} / \mathrm{ml}$ welding fume sample and $1 \times 10^{6} \mathrm{RAW} 264.7$ cells. Data presented are means of \pm S.D. for 4 sets of experiments. $\left(^{*}\right)$ indicate a significant increase in lipid peroxidation compared to control. $(+)$ indicate significant difference between metal types at the same sizes. $(P<0.05)$

throughout our various ESR measurements $\left(\mathrm{H}_{2} \mathrm{O}_{2}\right.$, cellular and direct whole fume) was the ability of stainless steel fumes to generate higher amounts of free radicals than mild steel. Animal studies indicate that stainless steel welding fumes induce more lung inflammation and injury compared to mild steel fumes [17] Elemental analysis of the fumes showed that stainless steel contained two transition metals not found in mild steel, chromium and nickel. Both chromium and nickel have had extensive research performed on their reactivity and abilities to produce ROS in biological systems [36]. These metals have been shown to be highly toxic and result in generation of ROS and associated damage. Furthermore,

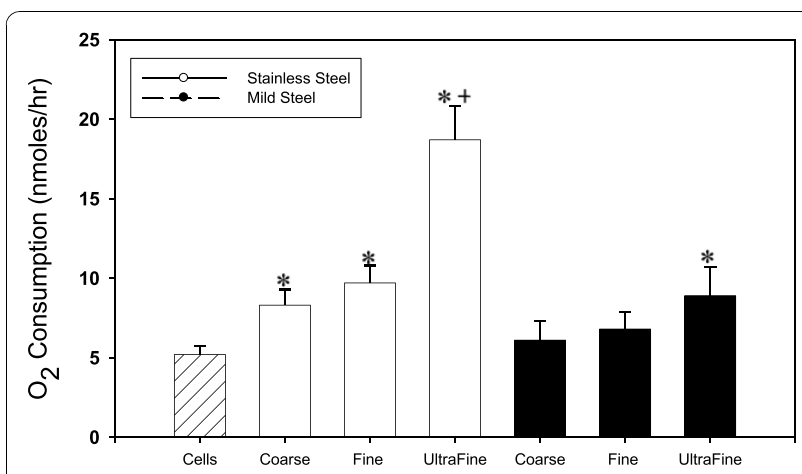

Figure 10 Oxygen consumption in welding fume stimulated RAW 264.7 cells. Incubation mixtures contain $3 \times 10^{6}$ RAW 264.7 cells $+500 \mu \mathrm{g} / \mathrm{ml}$ welding fume sample. Data presented are means of \pm S.D. for 4 sets of experiments. $\left(^{*}\right)$ indicate a significant increase in oxygen consumption compared to control. $(+)$ indicate significant difference between metal types at the same sizes. $(P<0.05)$ their ability to cycle through transition states once in a cellular system can lead to extensive and ongoing ROS production. This metal cycling ability was demonstrated in our investigation by the ESR spectra results showing the production of $\mathrm{Cr}(\mathrm{V})$ in stainless steel fume exposed cells. This $\mathrm{Cr}(\mathrm{V})$ radical signal came from the reduction of $\mathrm{Cr}(\mathrm{VI})$ in the welding fume in a cellular system. This $\mathrm{Cr}(\mathrm{VI}) \rightarrow \mathrm{Cr}(\mathrm{V})$ system has been researched and shown to be toxic and to responsible for the generation ROS associated damage [37].

The relationship between free radical generation and different sizes at equal mass was also investigated to determine the effect on free radical generation after exposure to $\mathrm{H}_{2} \mathrm{O}_{2}$. The greatest free radical generation was observed when analyzing the ultrafine particles demonstrating that reactivity of the particles is dependent on available surface area with equal mass. Generated welding fumes are long chains of agglomerated particles which are trapped on filters in size groups. However, the large chains are actually made up of many smaller primary particles linked together, creating a much higher surface area at equal mass than spherical particles that are more commonly observed in the environment and workplace. The welding fume chains formed under the high heat conditions of welding acts synergistically to create fresh particles of a high surface area which generate reactive species. Freshly generated welding fume has been previously reported to be more biologically active in an animal model [16].

Welding fumes were also found to cause lipid peroxidation, an indicator of cell membrane damage and precursor for other radical generation systems. Lipid 


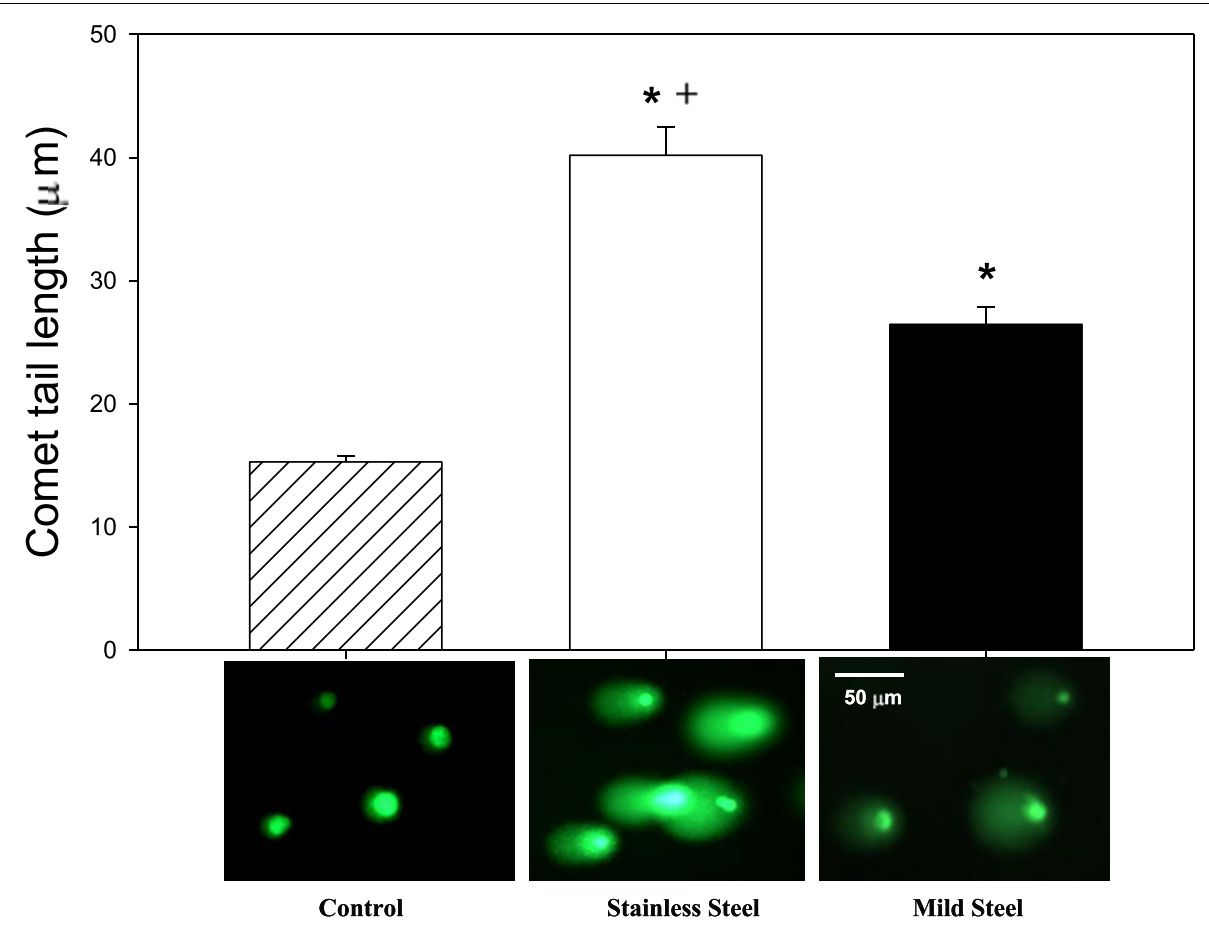

Figure 11 Comet assay results after incubation of RAW 264.7 cells for $1 \mathrm{~h}$ exposed to $250 \mu \mathrm{g} / \mathrm{ml}$ welding fume. Data presented are means of \pm S.D. for 4 sets of experiments. $\left.{ }^{*}\right)$ indicate a significant increase in DNA damage compared to control. ( + ) indicate significant difference between metal types at the same sizes. $(P<0.05)$

peroxidation results in the release of lipid-derived radicals ( ${ }^{*}$; $\mathrm{RO}^{*}$ and ROO') [38], which can lead to a cascade effect and release reactive iron [39] causing the generation of more ROS. Lipid peroxidation and its effects have been found to cause DNA damage [40] and may function as tumor initiators [41]. Once again the stainless steel fumes cause significantly greater damage to the cells than mild steel. This same trend, as well as a trend in smaller size i.e. greater surface area was also demonstrated in $\mathrm{H}_{2} \mathrm{O}_{2}$ generation, $\mathrm{O}_{2}$ consumption and DNA damage in exposed RAW 264.7 cells. $\mathrm{H}_{2} \mathrm{O}_{2}$ generation and $\mathrm{O}_{2}$ consumption are indicators of a respiratory burst in the exposed cells creating downstream effects and activation of inflammatory pathways and signaling. The significantly higher DNA damage observed in the stainless steel fumes may be due to the different metals present. Hydroxyl radicals generated with certain metals, such as nickel and copper, exhibit less reactivity with DNA. Possible reasons for this non-reactivity include; that $\mathrm{OH}$ radicals are generated within the domain of certain macromolecules and, therefore, are not able to exhibit significant reactivity and the structural contribution of metal toward DNA-binding and metal interactions with the DNA $[42,43]$. The results from our study show that $\mathrm{OH}$ radicals generated from both welding fumes have the potential to cause DNA damage with stainless steel containing $\mathrm{Cr}$ causing significantly greater DNA damage. In addition, $\mathrm{H}_{2} \mathrm{O}_{2}$ and $\mathrm{OH}$ generated by cells exposed to welding fume may cause other cellular damage via mechanisms associated with reactions initiated by ROS, for example, dG hydroxylation and protein-DNA cross-links. Furthermore these ROS may also cause activation of nuclear transcription factors, such as NF- $\kappa \mathrm{B}$, over-expression of certain oncogenes and induction of p53 mutation [44,45].

\section{Conclusions}

The significant increase in oxidative damage observed in the cellular exposures correlates well with the results as determined by ESR of ${ }^{\circ} \mathrm{OH}$ generation in size and type of welding fumes, indicating the influence of metal type and transition state on radical production as well as associated damage. Our results demonstrate that both types of welding fumes are able to generate ROS and ROS-related damage over a range of particle sizes; however, the stainless steel fumes consistently showed a significantly higher reactivity and radical generation capacity. The chemical composition of the steel had a significant impact on the ROS generation capacity with the stainless steel, but not mild steel, containing $\mathrm{Cr}$ and $\mathrm{Ni}$ causing more damage than the mild steel. Both materials contained $\mathrm{Fe}$, a known Fenton radical producer, $\mathrm{Mn}$ and $\mathrm{Cu}$. Our results suggest that the marked 
difference between the radicals produced in the two types of fumes is due to the presence of $\mathrm{Cr}$ found in the stainless steel. Cr has been shown in many investigations to a cause a number of toxicities. It is also noted that the smaller particle size of the fume the greater the ROS potential at equal mass with the $0.180-0.032 \mu \mathrm{m}$ sizes showing the most reactivity in both types of welding fume which can penetrate deepest into the lung of an exposed welder. Our results further demonstrated that the freshly generated fumes were more reactive and caused more oxidative damage than the aged particles, indicating that metal transition state also plays an important role in welding fume reactivity. Therefore, our results suggest that welding fumes may cause acute lung injury. Since type of fume generated, particle size, and elapsed time after generation of the welding exposure are significant factors in radical generation and particle deposition these factors should be considered when developing protective strategies.

\section{Methods}

\section{Reagents}

Chelex 100 resin was purchased from Bio-Rad Laboratories (Richmond, CA, USA). Phosphate-buffered saline (PBS), $\left(\mathrm{KH}_{2} \mathrm{PO}_{4}(1.06 \mathrm{mM}), \mathrm{Na}_{2} \mathrm{HPO}_{4}\right.$ (5.6 mM), $\mathrm{NaCl}$ (154 mM), pH 7.4), was purchased from Biowhittaker Inc. (Walkersville, MD, USA). The PBS was treated with Chelex 100 to remove transition metal ion contaminants. Dulbecco's modified eagles medium (DMEM), 5,5dimethyl-1-pyroline-oxide (DMPO), fetal bovine serum (FBS), $\mathrm{FeSO}_{4}, \mathrm{H}_{2} \mathrm{O}_{2}$, and penicillin/streptomycin were purchased from Sigma Chemical Company (St. Louis, MO, USA). The spin trap, DMPO, was purified by charcoal decolorization and vacuum distillation and was free of ESR detectable impurities. Quartz sample tubes were purchased from Wilmad Glass (Buena, NJ, USA).

\section{Cell culture}

RAW 264.7 mouse peritoneal monocytes were purchased from American Type Culture Collection (Rockville, MD). RAW 264.7 cells are commonly used and have been found to respond to particle exposure in a manner similar to primary alveolar macrophages [46-49]. RAW 264.7 cells were cultured in DMEM with 10\% FBS, $2 \mathrm{mM}$ L-glutamine, and $50 \mathrm{mg} / \mathrm{ml} \mathrm{pen} / \mathrm{strep}$ at $37^{\circ} \mathrm{C}$ in a $5 \% \mathrm{CO}_{2}$ incubator. Cells were split after confluence approximately every 3 days.

\section{Generation and collection of welding fumes}

The welding fume generation system was similar to that previously outlined [22]. Briefly, the generation system consisted of a welding power source (Power Wave 455, Lincoln Electric, Cleveland, $\mathrm{OH}$ ), an automated, programmable six-axis robotic arm (Model $100 \mathrm{Bi}$, Lincoln
Electric), a water cooled arc welding torch (WC 650 amp, Lincoln Electric), a wire feeder that supplied the wire to the torch at a programmed rate up to 300 inches/min, and an automatic welding torch cleaner that kept the welding nozzle free of debris and spatter. Gas metal arc welding was performed using a mild steel electrode (carbon steel ER70S-6, Lincoln Electric) or a stainless steel electrode (Blue Max E308LSi wire, Lincoln Electric). Welding took place on A36 carbon steel plates for fume collection times of $20 \mathrm{~min}$ at $25 \mathrm{~V}$ and 200 amps. During welding, a shielding gas combination of $95 \%$ Ar and $5 \% \mathrm{CO}_{2}$ (Airgas Co., Morgantown, WV) was continually delivered to the welding nozzle at an air flow of $20 \mathrm{~L} / \mathrm{min}$.

Figure 1 shows an outline of the generation and collection system. The system is contained in three rooms; the control room, the robotic arm welding fume generator and the fume collection chamber. All three rooms were separated from each other.

Aerodynamically size-selected aerosol samples were collected with the Micro-Orifice Uniform Deposit Impactor (MOUDI), model \# 110 and Nano-MOUDI MSP Model \#115, with rotator (MSP, Inc., Minneapolis, MN, USA). This MOUDI/Nano-MOUDI arraignment provided a 15-stage research-grade cascade impactor. Each filter stage has a cutoff size with particles collected at each stage being aerodynamically size-selected between stage sizes. Cutoff sizes were; 18, 10, 5.6,3.2, 1.8, 1.0, 0.56, $0.32,0.18,0.10,0.006,0.03,0.02,0.01 \mu \mathrm{m}$ and the final filter. Filters used for ESR and cellular exposures were from Millipore Corp. (Billerica, MA, USA) $47 \mathrm{~mm}, 0.8$ $\mu \mathrm{m}$, PVC model PVC0847600. PVC was selected because it has previously been demonstrated to have no effect in the free radical analysis. The MOUDI substrates are normally coated with grease to ensure adherence of deposited particles and to avoid bounce of large particles to lower stages of the impactor. However, grease can alter the surface of collected aerosol particles and is not suitable for use in collecting samples for free radical analysis. Therefore, the cascade impactor was operated without grease substrates to collect and fractionate the welding fume. Filters were collected for $20 \mathrm{~min}$. Filters were then split into 3 groups for either 1 hour, 24 hour or 1 week post generation analysis.

Filter suspensions, which were used for $\mathrm{H}_{2} \mathrm{O}_{2}$, lipid peroxidation, oxygen consumption and DNA damage analysis, were prepared by splitting the filters into three size groups. For our study the size groups were defined as ultrafine $(0.01-0.056 \mu \mathrm{m})$, fine $(0.1-1.0 \mu \mathrm{m})$ and coarse $(1.8-18 \mu \mathrm{m})$ particles. The groups consisted of five filters each of which were placed in PBS. Pre- and post filter weights were used to prepare a final concentration of $1 \mathrm{mg} / \mathrm{ml}$ welding fume suspension. The slurry was centrifuged, and the fume suspension was decanted 
from the filter pellet. A clean control suspension was also prepared at a ratio of 4 filters $/ 1 \mathrm{ml}$ PBS.

\section{Welding particle morphology, transmission electron microscopy (TEM)}

Welding fume samples, collected separately from the fumes used in free radial analysis, were collected at 30minute intervals during $3 \mathrm{~h}$ of welding directly onto formvar-coated TEM grids and viewed using a JEOL 1220 transmission electron microscope (JOEL, Inc.).

\section{Welding particle size distribution}

Particle size distribution was determined by using a Micro-Orifice Uniform Deposit Impactor (MOUDI) model \# 110 which is intended for the general purpose aerosol sampling, and a Nano-MOUDI (MSP Model 115) that is specifically designed for sampling aerosols in the size range down to $0.010 \mu \mathrm{m}$.

\section{Welding particle metal content analysis}

Mild and stainless steel welding particles were collected onto $5.0 \mathrm{~mm}$ polyvinyl chloride membrane filters in 37 $\mathrm{mm}$ cassettes during $30 \mathrm{~min}$ of welding. Metal analysis samples were collected separately from the samples used for free radical analysis. The particle samples were digested and the metals analyzed by inductively coupled plasma atomic emission spectroscopy (ICP-AES) by Clayton Group Services (A Bureau Vertis Company, Novi, MI) as coordinated with the Division of Applied Research and Technology (DART, Cincinnati, OH) according to NIOSH method 7300 modified for microwave digestion [50]. Metal content of blank filters also was analyzed for control purposes.

\section{Free radical measurements}

ESR spin trapping was used to detect short-lived free radical intermediates. Hydroxyl radicals were measured using the addition-type reaction of a short-lived radical with a compound (spin trap) to form a relatively longlived paramagnetic free radical product (spin adduct), which can then be studied using conventional ESR. For hydroxyl radical measurements on individual filter sizes, reactants were mixed in test tubes at a final volume of $1.0 \mathrm{ml}$ of $\mathrm{PBS}$ in the presence of $1 \mathrm{mM}$ $\mathrm{H}_{2} \mathrm{O}_{2}$. The reaction mixture was then transferred to a quartz flat cell for ESR measurement. Experiments were performed at room temperature and under ambient air. The concentrations given in the figure legends are final concentrations. The intensity of the signal is used to measure the relative amount of short-lived radicals trapped, and the hyperfine couplings of the spin adduct are characteristic of the original trapped radicals. Spin trapping is the method of choice for detection and identification of free radical generation due to its specificity and sensitivity. All ESR measurements were conducted using a Bruker EMX spectrometer (Bruker Instruments Inc. Billerica, MA 01821, USA) and a flat cell assembly. Hyperfine couplings were measured (to $0.1 \mathrm{G}$ ) directly from magnetic field separation using potassium tetraperoxochromate $\left(\mathrm{K}_{3} \mathrm{CrO}_{8}\right)$ and 1,1-diphenyl-2-picrylhydrazyl (DPPH) as reference standards $[51,52]$. The relative radical concentration was estimated by multiplying half of the peak height by $\left(\Delta \mathrm{H}_{\mathrm{pp}}\right)^{2}$, where $\Delta \mathrm{H}_{\mathrm{pp}}$ represents peakto peak width. The Acquisit program was used for data acquisitions and analyses (Bruker Instruments Inc. Billerica, MA 01821, USA).

\section{Radicals trapped by bubbler}

Freshly generated total welding particle reactivity was measured using a midget bubbler (Ace Glass, Vineland NJ) containing a reaction mixture made up of $\mathrm{H}_{2} \mathrm{O}_{2}(10$ $\mathrm{mM})$ DMPO (100 mM), and PBS to instantly trap generated radicals for ESR measurement. The midget bubbler was attached to a collection tube with a flow rate of $1 \mathrm{~L} / \mathrm{min}$ positioned approximately 18 inches from the welding surface in order to directly collect the freshly generated fume. Fume was collected for $20 \mathrm{~min}$. The reaction mixture was then immediately measured using ESR in order to determine $\mathrm{OH}$ generation from freshly generated whole fume.

\section{Grouped filters}

Grouped filter suspensions, were used for $\mathrm{H}_{2} \mathrm{O}_{2}$, lipid peroxidation, $\mathrm{O}_{2}$ consumption and DNA damage analysis. Suspensions were prepared by splitting the filters into three size groups. For this study the size groups were defined as ultrafine $(0.01-0.056 \mu \mathrm{m})$, fine $(0.10$ $1.0 \mu \mathrm{m})$ and coarse $(1.8-18 \mu \mathrm{m})$ particles. The groups consisted of five filters each of which were placed in PBS and blended on ice into a fine slurry using a Tissue Tearor (Biospec Products Inc. Racine, WI). Preand post filter weights were used to prepare a final suspension of $1 \mathrm{mg} / \mathrm{ml}$ welding fume. The slurry was centrifuged, and the welding fume suspension was decanted from the filter pellet. A clean control suspension was also prepared at a ratio of 5 filters $/ 1 \mathrm{ml}$ PBS. Suspension not used immediately was aliquoted and frozen at $-70^{\circ} \mathrm{C}$.

\section{Lipid peroxidation}

Lipid peroxidation of RAW 264.7 mouse peritoneal monocytes was measured by using a colormetric assay for malondialdehyde (LPO-586 Oxis International Inc. Portland, OR, USA). A reaction mixture contained various size groups (refer to filter methods) of welding particle samples $[250 \mu \mathrm{g} / \mathrm{ml}], \mathrm{H}_{2} \mathrm{O}_{2}(1 \mathrm{mM})$ and $1 \times 10^{7}$ cells in a total volume of $1.0 \mathrm{ml}$ PBS (pH 7.4). A Fenton 
reaction, $\mathrm{FeSO}_{4}(1 \mathrm{mM}), \mathrm{H}_{2} \mathrm{O}_{2}(1 \mathrm{mM})$ and $1 \times 10^{7}$ cells, was also carried out as a positive control. The mixtures were exposed for $1 \mathrm{~h}$ in a shaking water bath at $37^{\circ} \mathrm{C}$. The measurement of lipid peroxidation is based on the reaction of a chromogenic reagent with malonaldehyde at $45^{\circ} \mathrm{C}[53,54]$. The absorbance of the supernate was measured at $586 \mathrm{~nm}$.

\section{$\mathrm{H}_{2} \mathrm{O}_{2}$ production}

$\mathrm{H}_{2} \mathrm{O}_{2}$ production was monitored using a Bioxytech quantitative hydrogen peroxide assay kit $\left(\mathrm{H}_{2} \mathrm{O}_{2}-560\right.$, Oxis International Inc. Portland, OR, USA). Measurements were made on a system containing $5 \times 10^{6}$ RAW 264.7 mouse peritoneal monocytes/ml in $\mathrm{pH}$ 7.4 PBS and exposing them to the size groupings (refer to filter methods) of welding particle solution. Cells were exposed to welding particle solution [250 $\mu \mathrm{g} / \mathrm{ml}]$, for 30 minutes in a $37^{\circ} \mathrm{C}$ incubator. Absorbance was monitored at a wavelength of $560 \mathrm{~nm}$ using a Spectra Max 250 multi-well plate reader (Molecular Devices, Sunnyvale, CA, USA).

\section{$\mathrm{O}_{2}$ consumption}

Oxygen consumption measurements were carried out using a Gilson oxygraph (Gilson Medical Electronics, Middleton, WI). Measurements were made on a system containing $3 \times 10^{6}$ RAW 264.7 mouse peritoneal monocytes $/ \mathrm{mL}$ and welding particle solution $[500 \mu \mathrm{g} / \mathrm{ml}]$, in $\mathrm{pH} 7.4$ phosphate buffer. The oxygraph was calibrated with media and equilibrated with known concentrations of oxygen.

\section{DNA damage, Comet assay}

The Comet assay was performed using methods described in the Trevigen (Gaithersburg, Md., U.S.A.) assay kit. A typical reaction mixture contained welding particle solution $[250 \mu \mathrm{g} / \mathrm{ml}], \mathrm{H}_{2} \mathrm{O}_{2}(1 \mathrm{mM})$, and $1 \times$ $10^{7}$ RAW 264.7 mouse peritoneal monocytes cells brought to a total volume of $1.0 \mathrm{~mL}$ in PBS (pH 7.4). Briefly, (all steps performed in the dark or low light conditions) RAW264.7 mouse cells were exposed to the various sized welding fume and incubated in media at $37^{\circ}$ $\mathrm{C}$ for $1 \mathrm{~h}$. The cells were washed $(2 \times)$ with PBS and combined with LMAgarose, then pipetted onto a Comet slide. The slide was placed in a refrigerator for $30 \mathrm{~min}$, immersed in lysis solution, chilled for $60 \mathrm{~min}$, and then immersed in alkaline solution for $55 \mathrm{~min}$. Slides were placed in a horizontal electrophoresis chamber for 40 $\mathrm{min}$ at $300 \mathrm{~mA}$. Slides were washed and SYBR green stain was added to each. Slides were visualized using fluorescence microscopy, with an image capturing system (Olympus AX70 and sample PCI, Compix,
Cranberry Township, PA). A minimum of 50 cells were scored for each sample at $400 \times$ magnification. The distance between the edge of the head and the end of the tail was measured using an automated image analysis system (Optimas 6.51, Media Cybernetics Inc., Silver Spring, Md) [55,56].

\section{Statistics}

Data were expressed as mean \pm standard error of the mean (SEM) $(n=4)$ for each group. One-way ANOVA test was performed using SigmaStat statistical software (Jandel Scientific, San Rafael, CA, USA) to compare the responses between treatments. Statistical significance was set at $\mathrm{p}<0.05$.

\section{Abbreviations}

Defined in text.

\section{Acknowledgements}

Disclaimer: The findings and conclusions of this paper have not been formally dissemination by NIOSH and should not be construed to represent any agency determination or policy.

\section{Authors' contributions}

SSL, BTC, DF and JMA contributed to the idea and design of the study. SSL, BTC and SGS carried out welding generation and particle collection. SSL and AJK carried out all electron spin resonance and toxicity measurements. DSB carried out EM analysis of particles. All authors read and approved the final manuscript.

\section{Competing interests}

The authors declare that they have no competing interests.

Received: 25 June 2010 Accepted: 3 November 2010

Published: 3 November 2010

\section{References}

1. Bureau of Labor Statistics. [http://www.bls.gov/oes/current/oes514121. htm].

2. Moulin JJ, Wild P, Haguenoer JM, Faucon D, De Gaudemaris R, Mur JM, Mereau M, Gary Y, Toamain JP, Birembaut Y: A mortality study among mild steel and stainless steel welders. Br J Ind Med 1993, 50(3):234-43.

3. Simonato L, Fletcher AC, Andersen A, Anderson K, Becker N, ChangClaude J, Ferro G, Gérin M, Gray CN, Hansen KS: A historical prospective study of European stainless steel, mild steel, and shipyard welders. $\mathrm{Br} J$ Ind Med 1991, 48(3):145-54.

4. Zimmer AT, Biswas P: Characterization of the aerosols resulting from arc welding processes. J Aerosol Sci 2001, 32:993-1008.

5. Contreras GR, Chan-Yeung M: Bronchial reactions to exposure to welding fumes. Occup Environ Med 1997, 54(11):836-9.

6. Hannu T, Piipari R, Kasurinen H, Keskinen H, Tuppurainen M, Tuomi T: Occupational asthma due to manual metal-arc welding of special stainless steels. Eur Respir J 2005, 26(4):736-9.

7. d'Errico A, Pasian S, Baratti A, Zanelli R, Alfonzo S, Gilardi L, Beatrice F, Bena A, Costa G: A case-control study on occupational risk factors for sino-nasal cancer. Occup Environ Med 2009, 66(7):448-55.

8. Langård S: Nickel-related cancer in welders. Sci Total Environ 1994, 148(23):303-9, Review.

9. Antonini JM, Taylor MD, Millecchia L, Bebout AR, Roberts JR: Suppression in lung defense responses after bacterial infection in rats pretreated with different welding fumes. Toxicol Appl Pharmacol 2004, 200(3):206-18.

10. Anderson SE, Meade BJ, Butterworth LF, Munson AE: The humoral immune response of mice exposed to manual metal arc stainless steel-welding fumes. J Immunotoxicol 2007, 4(1):15-23. 
11. Antonini JM, Lewis $A B$, Roberts $J R$, Whaley DA: Pulmonary effects of welding fumes: review of worker and experimental animal studies. Am J Ind Med 2003, 43(4):350-60.

12. Sferlazza SJ, Beckett WS: The respiratory health of welders. Am Rev Respir Dis 1991, 143(5 Pt 1):1134-48.

13. Solano-Lopez C, Zeidler-Erdely PC, Hubbs AF, Reynolds SH, Roberts JR, Taylor MD, Young SH, Castranova V, Antonini JM: Welding fume exposure and associated inflammatory and hyperplastic changes in the lungs of tumor susceptible a/j mice. Toxicol Pathol 2006, 34(4):364-72.

14. Sobaszek $A$, Boulenguez $C$, Frimat $P$, Robin $H$, Haguenoer JM, Edme JL: Acute respiratory effects of exposure to stainless steel and mild steel welding fumes. J Occup Environ Med 2000, 42(9):923-31.

15. Liu HH, Wu YC, Chen HL: Production of ozone and reactive oxygen species after welding. Arch Environ Contam Toxicol 2007, 53(4):513-8.

16. Antonini JM, Clarke RW, Krishna Murthy GG, Sreekanthan P, Jenkins N, Eagar TW, Brain JD: Freshly generated stainless steel welding fume induces greater lung inflammation in rats as compared to aged fume. Toxicol Lett 1998, 98(1-2):77-86.

17. Taylor MD, Roberts JR, Leonard SS, Shi X, Antonini JM: Effects of welding fumes of differing composition and solubility on free radical production and acute lung injury and inflammation in rats. Toxicol Sci 2003, 75(1):181-91.

18. Stark M, Zubareb J, Jacovovitz R, Schwartz $Y$, Lerman $Y$, Grinberg N, Fireman E: HO-1 and VEGF gene expressions are time dependant during exposure to welding fumes. Cytokine 2009, 46(2):290-5.

19. Seel EA, Zaebst DD, Hein MJ, Liu J, Nowlin SJ, Chen P: Inter-rater agreement for a retrospective exposure assessment of asbestos, chromium, nickel and welding fumes in a study of lung cancer and ionizing radiation. Ann Occup Hyg 2007, 51(7):601-10.

20. Tessier DM, Pascal LE: Activation of MAP kinases by hexavalent chromium, manganese and nickel in human lung epithelial cells. Toxicol Lett 2006, 167(2):114-21.

21. Hewett P: Estimation of regional pulmonary deposition and exposure for fumes from SMAW and GMAW mild and stainless steel consumables. Am Ind Hyg Assoc J 1995, 56(2):136-42.

22. Antonini JM, Afshari AA, Stone S, Chen B, Schwegler-Berry D, Fletcher WG, Goldsmith WT, Vandestouwe KH, McKinney W, Castranova V, Frazer DG: Design, construction, and characterization of a novel robotic welding fume generator and inhalation exposure system for laboratory animals. J Occup Environ Hyg 2006, 3(4):194-203.

23. Jenkins NT, Pierce WM-G, Eagar TW: Particle Size Distribution of Gas Metal and Flux Cored Arc Welding Fumes. Welding J 2005, 84:156s-163s.

24. Leonard SS, Castranova V, Chen BT, Schwegler-Berry D, Hoover M, Piacitelli C, Gaughan D: Particle size dependent radical generation from Wildland fire smoke. Toxicology 2007, 236:103-113.

25. Antonini JM, Taylor MD, Zimmer AT, Roberts JR: Pulmonary responses to welding fumes: role of metal constituents. J Toxicol Environ Health A 2004 67(3):233-49, Review

26. du Plessis L, Laubscher P, Jooste J, du Plessis J, Franken A, van Aarde N, Eloff F: Flow cytometric analysis of the oxidative status in human peripheral blood mononuclear cells of workers exposed to welding fumes. J Occup Environ Hyg 2010, 7(6):367-74.

27. Vallyathan V, Castranova V, Pack D, Leonard S, Shumaker J, Hubbs AF, Shoemaker DA, Ramsey DM, Pretty JR, McLaurin JL, Khan A, Teass A: Freshly fractured quartz inhalation leads to enhanced lung injury and inflammation: potential role of free radicals. Am J Respir Crit Care Med 1995, 152:1003-1009.

28. Antonini JM, Lawryk NJ, Murthy GG, Brain JD: Effect of welding fume solubility on lung macrophage viability and function in vitro. J Toxicol Environ Health A 1999, 58(6):343-63.

29. McNeilly JD, Heal MR, Beverland IJ, Howe A, Gibson MD, Hibbs LR, MacNee W, Donaldson K: Soluble transition metals cause the proinflammatory effects of welding fumes in vitro. Toxicol Appl Pharmacol 2004, 196(1):95-107.

30. Zeidler-Erdely PC, Kashon ML, Battelli LA, Young SH, Erdely A, Roberts JR, Reynolds SH, Antonini JM: Pulmonary inflammation and tumor induction in lung tumor susceptible $\mathrm{A} / \mathrm{J}$ and resistant $\mathrm{C} 57 \mathrm{BL} / 6 \mathrm{~J}$ mice exposed to welding fume. Part Fibre Toxicol 2008, 5:12

31. Antonini JM, Leonard SS, Roberts JR, Solano-Lopez C, Young SH, Shi X Taylor MD: Effect of stainless steel manual metal arc welding fume on free radical production, DNA damage, and apoptosis induction. Mol Cell Biochem 2005, 279(1-2):17-23.

32. Edmé $J$, Shirali $P$, Mereau M, Sobaszek A, Boulenguez C, Diebold $F$, Haguenoer JM: Assessment of biological chromium among stainless steel and mild steel welders in relation to welding processes. Int Arch Occup Environ Health 1997, 70(4):237-42

33. Antonini JM, Roberts JR: Chromium in stainless steel welding fume suppresses lung defense responses against bacterial infection in rats. $J$ Immunotoxicol 2007, 4(2):117-27.

34. Alexopoulos EC, Cominos X, Trougakos IP, Lourda M, Gonos ES, Makropoulos $\mathrm{V}$ : Biological monitoring of hexavalent chromium and serum levels of the senescence biomarker apolipoprotein $\mathrm{j} /$ clusterin in welders. Bioinorg Chem Appl 2008, 420578.

35. Serageldin $M$, Reeves DW: Development of welding emission factors for $\mathrm{Cr}$ and $\mathrm{Cr}(\mathrm{VI})$ with a confidence level. J Air Waste Manag Assoc 2009, 59(5):619-26

36. Leonard SS, Harris GK, Shi X: Metal-induced oxidative stress and signal transduction. Free Radic Biol Med 2004, 37(12):1921-1942.

37. Leonard SS, Wang S, Castranova V, Vallyathan V, Shi X: Role of Molecular Oxygen in the Generation of hyrdroxyl and superoxide anion radicals during enzymatic $\mathrm{Cr}(\mathrm{VI})$ reducation and its implication to (CrVI)-induced carcinogenisis. J Environ Path Toxicol Oncol 2000, 19:49-60.

38. Shi $X$, Dalal NS, Vallyathan V: ESR evidence for the hydroxyl radical formation in aqueous suspension of quartz particles and its possible significance to lipid peroxidation in silicosis. J Toxicol Environ Health 1988, 25:237-245.

39. Vladimirov YA: In Free Radicals, Aging and Degenerative Diseases. Edited by: Johnson JE Jr, Walford R, Harman D, Miquel J. New York: Liss; 1986:141-195.

40. Vaca CE, Wilhelm J, Harms-Ringdahl M: Interaction of lipid peroxidation products with DNA. A review. Mutat Res 1988, 195:137-149.

41. Comporti M: Lipid peroxidation and cellular damage in toxic liver injury. Lab Invest 1985, 53(6):599-623.

42. Keyhani E, Abdi-Oskouei F, Attar F, Keyhani J: DNA strand breaks by metalinduced oxygen radicals in purified Salmonella typhimurium DNA. Ann N Y Acad Sci 2006, 1091:52-64.

43. Valko M, Morris $\mathrm{H}$, Cronin MT: Metals, toxicity and oxidative stress. Curr Med Chem 2005, 12(10):1161-208.

44. Chen F, Ding M, Lu Y, Leonard SS, Vallyathan V, Castranova V, Shi X: Participation of MAP kinase $\mathrm{p} 38$ and IkB kinase in chromium(VI)-induced NF-kB and AP-1 activation. J Environ Pathol Toxicol Oncol 2000, 19:231-238.

45. Shi X, Chiu A, Chen CT, Halliwell B, Castranova V, Vallyathan V: Reduction of chromium $(\mathrm{VI})$ and its relationship to carcinogenesis. J Toxicol Environ Health 1998, 2:101-118.

46. Hiura TS, Kaszubowski MP, Li N, Nel AE: Chemicals in diesel exhaust particles generate reactive oxygen radicals and induce apoptosis in macrophages. J Immunol 1999, 163(10):5582-91.

47. Jalava $\mathrm{PI}$, Salonen $\mathrm{RO}$, Hälinen $\mathrm{Al}$, Penttinen $\mathrm{P}$, Pennanen $\mathrm{AS}$, Sillanpää $\mathrm{M}$ Sandell E, Hillamo R, Hirvonen MR: In vitro inflammatory and cytotoxic effects of size-segregated particulate samples collected during longrange transport of wildfire smoke to Helsinki. Toxicol Appl Pharmacol 2006, 215(3):341-53.

48. Leonard SS, Roberts JR, Antonini JM, Castranova V, Shi X: $\mathrm{PbCrO}_{4}$ mediates cellular responses via reactive oxygen species. Mol Cell Biochem 2004, 255(1\&2):171-9.

49. Zhang Y, Fong CC, Wong MS, Tzang CH, Lai WP, Fong WF, Sui SF, Yang M: Molecular mechanisms of survival and apoptosis in RAW 264.7 macrophages under oxidative stress. Apoptosis 2005, 10(3):545-56.

50. NIOSH: Elements (ICP): Method 7300. Manual of Analytical Methods. 4 edition. US Dept of Health and Human Services publication No. 98-119. Washington, D.C.: NIOSH; 1994, 2.

51. Janzen EG, Blackburn BJ: Detection and identification of short-lived free radicals by an electron spin resonance trapping technique. J Am Chem Soc 1968, 90:5909-10.

52. Buettner GR: Spin trapping: ESR parameters of spin adducts. Free Rad Biol Med 1987, 3:259-303.

53. Brambilla G, Martelli A, Marinari UM: Is lipid peroxidation associated with DNA damage? Mutat Res 1989, 214(1):123-7.

54. Imamoglu N, Yerer MB, Donmez-Altuntas H, Saraymen R: Erythrocyte antioxidant enzyme activities and lipid peroxidation in the erythrocyte membrane of stainless-steel welders exposed to welding fumes and gases. Int J Hyg Environ Health 2008, 211(1-2):63-8. 
55. Collins AR: The comet assay for DNA damage and repair: principles, applications, and limitations. Mol Biotechnol 2004, 26(3):249-61.

56. Botta C, larmarcovai G, Chaspoul F, Sari-Minodier I, Pompili J, Orsière T, Bergé-Lefranc JL, Botta A, Gallice P, De Méo M: Assessment of occupational exposure to welding fumes by inductively coupled plasmamass spectroscopy and by the alkaline Comet assay. Environ $\mathrm{Mol}$ Mutagen 2006, 47(4):284-95.

doi:10.1186/1743-8977-7-32

Cite this article as: Leonard et al:: Comparison of stainless and mild steel welding fumes in generation of reactive oxygen species. Particle and Fibre Toxicology 2010 7:32.

Submit your next manuscript to BioMed Central and take full advantage of:

- Convenient online submission

- Thorough peer review

- No space constraints or color figure charges

- Immediate publication on acceptance

- Inclusion in PubMed, CAS, Scopus and Google Scholar

- Research which is freely available for redistribution

Submit your manuscript at www.biomedcentral.com/submit 